\title{
CANAdian InFanticide Legislation, 1948 AND 1955: REFLECTIONS ON THE Medicalization/Autopoiesis Debate
}

\author{
Kirsten Johnson Kramar, PhD \\ William D. Watson, PhD
}

\begin{abstract}
This article provides a sociological analysis of the discursive interpretations of the criminal law mitigation frameworks underpinning infanticide law in England and Canada. The passage of infanticide legislation by the Canadian Parliament in 1948 and 1955 is described. The account is contrasted with Tony Ward's analysis of the passage of English legislation in 1922 and 1938. The Canadian legislation of 1948 was based on the English Infanticide Act of 1922. Ward claims that his account shows that, despite obvious appearances and the views of sociolegal commentators writing during the 1980s and 1990s, infanticide law is not an example of the medicalization of women's deviance but, if anything, more closely exemplifies law as an autopoietic system of communication which "enslaves" medical concepts, adapting them for its own strictly legal purposes. We argue that, while Ward's critique of the medicalization interpretation of infanticide law is broadly apposite, autopoiesis theory provides an overwrought alternative. This is especially true for the Canadian legislation.
\end{abstract}

Résumé. Cet article donne une analyse sociologique des interprétations discursives des cadres d'atténuation du droit pénal qui sont à la base de la législation en matière d'infanticide en Angleterre et au Canada. On y décrit l'adoption de la législation en matière d'infanticide par le Parlement canadien en 1948 et en 1955. La version fait contraste à l'analyse de Tony Ward sur l'adoption de la législation anglaise en 1922 et en 1938. La législation canadienne de 1948 fut basée sur la English Infanticide Act de 1922. M. Ward estime que sa version montre que, malgré des apparences évidentes et des points de vue de commentateurs socio-juridiques écrits pendant les années 1980 et 1990, la législation en la matière n'est pas un exemple de médicalisation de la déviance féminine, mais au contraire, illustre la législation en tant que système autopoiétique de communication qui « asservit » les concepts médicaux et les adapte pour ses propres besoins strictement juridiques. Nous faisons valoir que, bien que la critique de Ward sur l'interprétation de médicalisation de la législation en matière d'infanticide soit juste dans ses grandes lignes, la théorie de l'autopoièse s'avère une alternative tarabiscotée. Ceci est particulièrement le cas de la législation canadienne. 


\section{INTRODUCTION}

In this paper, we trace the background and passage of Canada's infanticide legislation, passed in 1948 in partial emulation of the English Act of 1922, and the amendment of the Canadian legislation in 1955. We contrast our account of the Canadian developments with Tony Ward's detailed history of the passage of the English Infanticide Act of 1922 and its amendment in 1938 (Ward 1999). Ward offers this history as an important element of a more broadly based challenge to the established interpretation of infanticide law as a clear-cut instance of the medicalization of women's deviance (see, for instance, Comack 1987; Edwards 1984; Scutt 1981; Showalter 1985; Smart 1989; 1992:16-18; and see discussions in Laster 1989; O’Donovan 1984; Osborne 1987; Wilczynksi 1991; 1997). Ward claims that, quite contrary to the medicalization thesis, infanticide law, even in its most psychiatrically informed version, "involved a reconstruction of medical concepts to fit the law" (Ward 1999:174; emphasis in original). He represents his position as "ow [ing] something to Teubner's (1989) 'autopoietic' theory of law" (Ward 1999:174; see Teubner 1988; 1989; 1990; 1993; see also Luhmann 1988; 1985:281-8), although he recognizes the divergences between his account and autopoiesis theory. If Ward is right, it is a telling example of the problems of the medicalization approach to the law/ psychiatry relation. Contemporary infanticide law, which only applies to the biological mother of a victim in the first year of life, and which offers mitigation from a possible murder conviction, seems to link women's deviance to reproductive difference and pathology in the most obvious and unequivocal way. The relevant section of the Criminal Code of Can$a d a$, s. 233, reads as follows:

Infanticide - A female person commits infanticide when by a wilful act or omission she causes the death of her newly-born child, if at the time of the act or omission she is not fully recovered from the effects of giving birth to the child and by reason thereof or of the effect of lactation consequent on the birth of the child the balance of her mind is then disturbed.

The implication drawn by the feminist medicalization theorists is that the law, following psychiatry, deems women inherently prone to mental instability as a result of the normal physiological functions associated with motherhood. Ward insists that this interpretation is a rush to judgement, and that a closer investigation of the concerns of the legislators, and their contemporaries in psychiatric medicine, reveals that, for the most part, the law developed quite separately from psychiatric thinking about postpartum mental illness and infanticide. 
The 1922 Act confined its mitigation to mothers of "newly born" babies (the coverage was extended to mothers of babies up to one year old in 1938). Ward shows that the biological theory referenced in the 1922 Act, that women in childbirth, especially in difficult circumstances, were prone to temporarily lose reason or self-control, was a lay, rather than a psychiatric, theory (Ward 1999:165-6). This paternalistic "common sense" worked hand-in-hand with juror and judicial sympathy for these mothers which turned on an appreciation of their status as young, socially deprived victims of seduction. Jurors were so sympathetic to these women they were disinclined to convict them, whatever the evidence. Infanticide was thought of as only a quasi-criminal act since there was a range of sociological factors which very strongly mitigated individual responsibility. The women's "irrational" behaviour or "impulses" were seen as motivated not by "evil" but "morally pure" intentions; since women who killed their illegitimate babies were conforming to society's moral standards, they were viewed as acting both "irrationally" and "properly." Men who, by seducing and abandoning these women, failed to live up to society's moral standards were the "real criminals."

Psychiatric specialists were more concerned about poor women, often with many children, who killed their babies due to psychoses brought on by the strains of lactation in conditions of poverty. While there is a certain element of reproductive biology in this account of the women's "exhaustion psychosis," the theory was primarily socioeconomic. The psychiatrists generally concluded that young mothers who killed their illegitimate children at, or shortly after, childbirth were not usually mentally ill. Ward accepts that the 1938 Act, which amended the 1922 provisions to include a reference to the effects of lactation, and which extended the coverage to crimes involving victims under the age of twelve months, was an eventual response to the dominant biosocial theories. It can hardly be seen as a colonization of law by medicine, since it only made infanticide more psychiatrically plausible than was the case under the biological theory of the 1922 Act. A direct reference to the social exigencies which medical scientists believed triggered exhaustion psychoses, which would have conceptually opened the law to social mitigation in terms of guilt or innocence for murder, was dropped in order to ensure passage of the Act (Ward 1999:173).

For Ward, these circumstances chime with legal autopoiesis theory. According to Luhmann's theory, discourses such as law should be understood as systems of communication operating independently of the intentions, strategies, and even consciousness of "participating" individuals. Discourses, understood in this way, have become increasingly fragmented (Luhmann 1982), with each discourse constructing its own 
categories, that is, its own realities, which are radically incompatible with those of alternative discourses. Law, viewed as an especially basic discourse fundamental to the possibility of society (Luhmann 1989:105), is no exception. From this perspective, medicine cannot colonize law (any more than law can colonize medicine), but can only create discursive "noise" that places external pressures on law to which law responds by developing, through legal procedures, new legal categories which, despite appearances, are never "medicolegal" in a genuine sense. Rather, "[1]aw 'enslaves' psychiatric concepts, putting them to work to answer its own questions about responsibility, etc." (Ward 1999:174; see Teubner 1989:746-9).

Ward accepts that his own account diverges from formal autopoiesis theory in that, while he shows that the biological theory embodied in the 1922 Act was not one associated with psychiatric medicine, it nevertheless pre-existed its legal institution as a lay understanding. Luhman's account of increasingly fragmented discourses claims that law becomes more separate from both scientific and "common sense" discourses (Teubner 1989:742; c.f. Ward 1998). In addition, while Ward rejects the medicalization thesis, he concedes that the 1938 Act was responsive to psychiatric theory.

We have argued elsewhere (Kramar and Watson 2006) that, while Ward successfully demonstrates that the 1922 Act did not reflect contemporary psychiatric orthodoxy and, indeed, that the legislators were not concerned with psychiatric theory, there was a clear strand of distinctly biological theorizing that ran alongside, and was entangled with, the dominant socioeconomic theories. We also argued that infanticide law may have facilitated the medicalization of infanticide in the decades between its passage and the present day, whatever the intentions and knowledge-base of legislators. As a result, Ward's claim that infanticide law demonstrates legal autopoiesis more than medicalization is, at the least, a simplification. Still, we accept that Ward's account of the development of the legislation puts a considerable dent in even the more nuanced versions of the medicalization interpretation. ${ }^{1}$

Here we provide a history of the passage of the Canadian legislation in 1948, and its amendment in 1955. We show that, in terms of the understandings and intentions of legislators at least, the medicaliza-

1. In advancing this claim, Ward rejects the medicalization thesis more forcefully than commentators like O'Donovan who merely view the medicalization interpretation of the 1922 Act as lacking sufficient nuance, and who insist the Act: "was the product not of 19th century medical theory about the effects of childbirth, but of judicial effort to avoid death sentences which were not going to be executed. But medical theory provided a convenient reason for changing the law" (O'Donovan 1984:261). 
tion interpretation is even less apposite than in the English case. There was no endorsement of any biological theory, lay or psychiatric, or of any other kind of psychiatric theory. This was despite the existence of a long-standing psychiatric debate regarding infanticide, partly stimulated by the passage and operation of the English Act of 1922, and the recent emergence of a new psychiatric orthodoxy regarding postpartum mental illnesses. This orthodoxy was endorsed by a leading Canadian psychiatrist.

Equally, however, the application of formal legal autopoiesis theory to these developments would be even more overwrought than in the English case. The prosaic and entirely explicit legal concerns of the Canadian parliamentarians are not illuminated by the light of autopoiesis theory, with its ineluctable systemic enslavement of external discursive items working over the heads, or behind the backs, of participants. Canadian infanticide law is a product of purposeful, even pithy, legal policy analysis conducted partly in the Canadian House of Commons by Members of Parliament experienced in the workings of the law.

The medicalization and autopoiesis theories, as something like opposite ends of an explanatory spectrum, have become the two most influential ways of looking at the law/psychiatry relation. It therefore comes as no surprise that they have both been applied to the example of infanticide law. The strongest versions of each approach, such as Foucault's programmatic rendition of the psychiatrization of the law as the wholesale subversion of legal doctrine and transformation of legal and extralegal modes of government (Foucault 1978), and Luhmann's all or nothing version of autopoiesis (see King 1993:224; Smith 2004:323-324), are broadly incompatible. For Luhmann, law never wavers in its focus on distinguishing between the illegal and the legal, and thus radically reconstitutes extra-legal knowledge to this end. For Foucault, modern government is ushered in by the progressive replacement of the illegal/ legal distinction with the healthy/pathological distinction in the criminal justice arena and elsewhere. Less doctrinaire versions of each may, in theory, allow for mutual influence in the sense that the reconstruction of psychiatric knowledge in the legal arena still modifies law in a significant way. This does not, however, entail that any particular entanglement of psychiatric knowledge in legal processes can be theorized using a suitably nuanced medicalization or autopoiesis framework because the two approaches still present distinctive images of the law/psychiatry interaction which might not be borne out by examples. In particular, while defenders of legal autopoiesis theory highlight Teubner's accommodation of partial autopoiesis (King 1993:224-225; Smith 2004:323-324), they lose sight of the fact that Teubner frames partial autopoiesis entirely 
in terms of law's possibly inadequate autopoietic responses; law is seen as always aiming for autopoiesis, but never completely securing it. The legal system, like an organism forever managing the insult of infections, is never completely closed. The question in relation to infanticide law is whether either this, or the medicalization of law, are plausible images.

Social theories like autopoiesis theory are merely sets of claims about the ways the social world goes and why, although committed adherents to specific theories (e.g., King 1993) and determined opponents of social theorizing (e.g., Valverde 2006) tend to hypostasize them as "theory," that is somehow more or other than this. Some theories are constructed so that a single empirical counterexample, or a more plausible account of a single example, will serve to disconfirm them. Not even the strongest versions of the medicalization and autopoiesis theories have this form. The analysis of the enactment and amendment of Canada's infanticide legislation offered below cannot, then, offer a test of these theories; it probes the applicability of two obvious approaches to infanticide law, which have been applied to infanticide law elsewhere, to the Canadian case. As such, it avers reservations about the medicalization and autopoiesis theories; these two sets of claims do not appear to illuminate how this little bit of the social world went and why.

\section{Ward's Account of the Passage of the English Acts}

The English and Canadian legislators of 1922 and 1948 respectively were addressing the same problems. Many of the women who killed their newly born babies were young, unmarried, and in disadvantaged social positions. As Ward (1999:166) notes,

... even the most radical exponents of a medical or biological view of crime, such as Heath's friend Havelock Ellis (1901:24) or the maverick psychiatrist L. Forbes Winslow (1912: 295) - not noted for his reticence in diagnosing insanity in women - understood infanticide as chiefly a product of social factors rather than the result of morbid personality.

Carl Heath (1908) was affiliated with the Society for the Abolition of Capital Punishment and argued that infanticide was the product of "morbid mental and physical conditions often resulting from childbirth, especially when taking place under unhappy conditions" (p. 10), and that "If there is any condition of mind which can rightly be described as insane, it is that in which a mother loses all maternal instinct" (as cited in Ward, 1999:166). The experts' patriarchal hybrid discourses of maternal responsibility easily connected the rejection of motherhood with insanity 
but mitigated the killing in relation to socioeconomic distress. Research by Higginbotham (1992) in the late 19th century English context, reveals that very few unwed mothers who killed their babies were found insane at trial (Ward 1999:166). Similarly, research by Kramar in the early 20th century Canadian context, reveals that convictions for capital murder were only achieved when the young unwed women confessed to killing the babies (Kramar 2005). The mandatory death penalties which accompanied these rare murder convictions were always commuted (Backhouse 1984; 1991; Kramar 2005; Ward 1999:164-5). That these problems provided the impetus for infanticide law, which was an attempt to fashion an appropriate homicide offence which could result in principled conviction and disposition, is accepted by all the commentators (see Comack 1987; Backhouse 1984; 1991; Edwards 1984; Kramar 2005; Kramar and Watson 2006; Laster 1989; O’Donovan 1984; Osborne 1987; Scutt 1981:7-9; Showalter 1985; Smart 1989; 1992; Ward 1999; Wilczynski 1991; 1997).

Ward begins his discussion of the English developments with the Royal Commission on Capital Punishment of 1866. The Commission's proposal for a special grievous bodily harm offence - where a baby was injured, not necessarily by the mother, and subsequently died in the first seven days of life - was not adopted. Opposition to any dilution in the legal principles underpinning murder doomed this and similar proposals developed over the subsequent decade (Ward 1999:169). The Commission heard testimony emphasizing both the untenable social circumstances of infanticidal mothers and, in terms of what Ward shows to be the lay common sense of the time rather than any theory of psychiatric medicine, women's constitutional weaknesses, especially as these might be manifest during childbirth (Ward 1999:165-6). The Home Secretary was able to draw on his experience dealing with the commutation of death sentences in some of these cases, revealing his profound sympathy for the women (Ward 1999:165).

The issue was revisited some forty years later while the Children Act 1908 was being considered. The Lord Chancellor attempted to make the death sentence discretionary for mothers who killed their babies in the first year of life; instead, in face of continued opposition to dilution of the principles associated with murder, the House of Lords adopted an amendment permitting a manslaughter conviction where the mother had not recovered from childbirth (Ward 1999:169-70). The measure was unable to secure parliamentary time, but was revived in 1921 following a highly publicized case. The Lord Chancellor challenged the proposal on the ground of vagueness, and the provisions adopted in the Act of 1922 were developed, allowing for a finding of infanticide, dis- 
positionally equivalent to manslaughter, where murder was charged, and restricting the new category of infanticide to cases where the baby was newly born and where the effects of childbirth had affected the balance of the mother's mind. As Ward makes clear, the form adopted reflects contemporary concerns which can easily be misread from the vantage of the present day. There was no discussion of, or even reference to, "puerperal insanity" (Ward 1999:170) which, affecting women at childbirth as a result of septicaemia, was the closest medical-psychiatric analogue of the lay theory of women's propensity to temporary derangement during childbirth. ${ }^{2}$ The considerations reflect only the confidently articulated views of the legislators regarding women's intimate experiences. However, there was direct consideration of the proper legal relevance of the biological theory. The Lord Chancellor was concerned to limit mitigation to evidence of concrete mental disturbance consequent childbirth, insisting (just like today's "medicalization" critics of infanticide law), that a "normal healthy woman" (Ward 1999:171) experiencing the rigours of childbirth, even where the child was illegitimate, should not be assumed to lack responsibility.

The 1938 amendment, extending the coverage of the Act to victims up to one year of age, and making reference to the effects of lactation, did reflect the psychiatric orthodoxy of the day. ${ }^{3}$ The lay theory of childbirth inducing derangement had not been accepted by medical specialists and puerperal insanity was argued to be irrelevant to infanticide because its victims would be too deranged to commit the offence (Hopwood 1927:96). ${ }^{4}$ Puerperal insanity was, in any case, increasingly out of vogue. Psychiatrists' interest was squarely on poor nursing mothers, often with many children, suffering "lactational insanity" conceived as an "exhaustion psychosis." The psychiatric orthodoxy was presented to legislators by no less a figure than the President of the Royal College of Physicians (Ward 1999:173). While Ward must concede, then, that the 1938 Act represents a legislative concession to psychiatric theory

2. In his survey of the history of puerperal psychosis diagnoses, Brockington (1996:200-205) distinguishes mental disorder caused by puerperal sepsis from functional puerperal psychoses but seems to assimilate "puerperal insanity" to the latter. However, this does not correspond to the unfolding contemporary usages, emphasized by Ward and others.

3. The expansion of the age limit to 12 months caused some concern amongst English legislators. The infanticide provision is intended to address the special circumstances of maternal neonaticide where a young single woman kills a newly born child within hours of birth following a concealed pregnancy and secret childbirth.

4. Hopwood's article appeared in The Journal of Mental Science, which later became the British Journal of Psychiatry. 
and expertise, it was only a correction of the lay theory embodied in the original legislation, reflective of a primarily socioeconomic, as opposed to biomedical, psychiatric orthodoxy. Thus, despite the reservations we have expressed elsewhere regarding Ward's characterization of the contemporary psychiatric thinking as lacking reductively biomedical and otherwise biological strands (Kramar and Watson 2006), his argument that no such theory was the basis of the biologism of either piece of English legislation seems sound.

\section{The Changing Psychiatric Consensus}

The psychiatric views reflected in the 1938 amendment, that "puerperal psychosis" was a dubious psychiatric category denoting a "condition" implausibly associated with infanticide, and that the psychiatric diminution of responsibility was more plausible in cases of "exhaustion psychosis" associated with poverty, were only temporarily orthodox. Psychiatric theory regarding postpartum mental illness moved even further from belief in the existence of any specific "insanities of reproduction." In 1942, six years before the enactment of the Canadian legislation, Ian Skottowe, MD, DPM, Medical Superintendent, Buckinghamshire County Mental Hospital and Physician for Nervous and Mental Disorders, Royal Buckinghamshire Hospital, declared that there was "no specific psychiatric syndrome which occurs exclusively in the child-bearing epoch" (Skottowe 1942:157). The emphasis was now on the occurrence of "ordinary" psychoses during the potentially stressful processes of pregnancy, childbirth, and the puerperium. Skottowe noted that other experts shared this view:

This is accepted by modern writers, including Kilpatrick and Tiebout (1926), Strecker and Ebaugh (1926), James (1935), Harris (1936), Smalldon (1940) and Cruikshank (1940) (Skottowe 1942:157-8).

In addition, the reproductive processes alone did not account for the presence of the ordinary psychoses; rather, "[t]here are always causal factors additional to the mere fact of child-bearing" (Skottowe 1942:163). Given the foci of the earlier theoretical formulations, these "causal factors" were unsurprising; emotional and economic hardship, heredity, and obstetric complications.

Reflecting on the difficulties of communicating the new orthodoxy, Skottowe adopted a tactic previously endorsed by those who favoured the categories of "lactational insanity" and "exhaustion psychosis": 
The old conception of "puerperal psychosis" (MacDonald, 1847) as a special entity is no longer tenable, although it is a convenient term in everyday use, so long as it is understood to refer to the setting in which the psychosis occurs and is not in itself a diagnosis. (Skottowe 1942:158)

Skottowe's position was, however, subtly but significantly different from those who had originally rejected "puerperal psychosis." The idea that there was nothing special or essential about postpartum mental illnesses became the orthodoxy, and has remained so to this day. "Lactational insanity" and "exhaustion psychosis" soon joined "puerperal insanity" as diagnoses of purely historical interest.

One of the articles cited by Skottowe as rejecting the concept of "puerperal psychosis" was published in the Canadian Medical Association Journal (Cruikshank 1940). W.H. Cruikshank worked at the Toronto Psychiatric Hospital, and delivered the paper to the Section of Neurology and Psychiatry of the Academy of Medicine a few months before its publication (Cruikshank 1940:571). In some contrast to Skottowe's forceful view that causal factors in addition to child-bearing are required to cause the psychotic reactions, Cruikshank rather glibly asserts that, with regard to "psychoses associated with pregnancy and the puerperium," "[o]bviously the chief etiological factor is pregnancy" (Cruikshank 1940:572). However, he emphasizes that many of the incidences of psychoses occurring during pregnancy, childbirth, and especially the puerperal period, are directly caused by toxaemia or exhaustion. Moreover, the majority of serious postpartum mental illnesses are to be understood as ordinary schizophrenic and manic-depressive psychoses occurring in these phases of the reproductive process (Cruikshank 1940:572). ${ }^{5}$ Thus, Cruikshank does not wholly reject the significance of puerperal toxaemia, but his focus is much broader than the old concept of "puerperal insanity"; embracing the significance of exhaustion, he emphasizes the more typical "everyday" psychoses. ${ }^{6}$ The new orthodoxy, in a cautious, but clearly identifiable, form was thereby represented in Canada prior to the enactment of the Canadian legislation in 1948. Certainly, Skottowe took him to be in sympathy with the contemporary viewpoint.

5. Cruikshank identifies 84 patients with pregnancy, childbirth, and puerperium related psychoses, of which 32 form a "toxic-exhaustive group," 28 form a "manic-depressive group," 22 form a "schizophrenic group," one suffers from "psychoneurosis," and one suffers from "psychosis with mental defect" (Cruikshank 1940:575).

6. Cruikshank reports that one of the patients in his study had committed infanticide. He does not identify the group to which she belonged, but the reference can be read as implying she was severely depressed (Cruikshank 1940:576). 


\section{The Canadian Infanticide Amendment (1948)}

These developments in psychiatric theory had not the slightest relevance for the Canadian legislators of 1948, who took their task to involve only the application of a proven legal solution to a persistent legal problem. When Mackenzie King's Liberal government introduced amendments to the Criminal Code that included "infanticide" as a form of "culpable homicide" in June of 1948 (Bill No. 377), lawmakers looked to the precedent of English legislation which had been in effect for over a quarter of a century. The reassurance provided by such a well-established legal framework was important because the infanticide provision was, in many respects, ground-breaking law in Canada.

Research covering the 19th century situation in provinces that would later become the Dominion of Canada documents the use of the Jacobean statue of 1623 "An act to prevent the destroying and murthering of Bastard Children" in cases of infanticide which, like murder, carried the penalty of death (Backhouse 1991). This concealment statute allowed an automatic assumption of guilt when it was proven that an unmarried woman had concealed the birth of even a stillborn baby. Even with this reverse onus element, convictions under this concealment statute were difficult to obtain and often thwarted by the "benefit of linen defence" when women brought evidence of having prepared items of clothing or bed linens for the baby. The defence established no malice aforethought, thereby ensuring acquittals on the criminal charge. The Jacobean concealment statute was repealed in English law in 1803 when the homicide framework was amended to allow a substitute conviction, upon an acquittal of murder for "concealment of birth," which carried a maximum penalty of two years' imprisonment (Backhouse 1984:123). Despite pressure to follow the English lead, it was not until 1836 that the Jacobean statute was repealed in all Canadian jurisdictions (Backhouse 1991:132) leaving both "concealment of birth" and "failure to obtain assistance in childbirth" as charges ancillary to murder in cases of infanticide. At the end of the 19th century in Canada, penalties for these crimes varied from their English counterparts. The maximum penalty for "failing to obtain assistance in childbirth" was life imprisonment while the maximum penalty for "concealment of birth" was seven years imprisonment (Backhouse 1991:133). By the mid 20th century the provisions were amended and their penalties reduced to five years' imprisonment for "neglect to obtain assistance in childbirth" and two years' imprisonment for "concealing body of a child" (Kramar 2005:197, n.6, n.9).

This legal framework, as it was applied in England, Wales, and Canada, failed to resolve the inherent problems of legal practice and philoso- 
phy created by juror sympathy. To the consternation of prosecutors, juror and judicial sympathy, based on the socioeconomic distress of young women perceived to be the victims of male seduction and abandonment, ensured that convictions for homicide were very rare in these cases, with jurors making the most of medical uncertainty regarding live birth. Many women were convicted for the less serious offence of "concealment of birth," while others avoided convictions altogether. Archival research by Backhouse covering the late 19th century in Ontario, Canada, for instance, reveals that "the charge of 'concealment of birth' was laid more frequently in ... infanticide cases than either murder or manslaughter," with convictions and acquittals for the charge being "about evenly matched" (1984:468). Where convictions for the lesser charges were obtained, a homicide had not been fully acknowledged.

The English Infanticide Act (1922) met the need for an offence between "murder and concealment" (Davies 1968 [1937-8]:323) mitigated by a degree of mental derangement somewhere between sanity and insanity. Manslaughter, as it was then constituted in English law, was unavailable for most cases of infanticide, since the acts were neither involuntary nor provoked in the legal sense and, even in cases where the death was due to neglect, juries would refuse to find for manslaughter (Davies 1968 [1937-8]:317). "Diminished responsibility" was not a basis for a manslaughter finding in England and Wales until its adoption in the English Homicide Act (1957). The infanticide law is taken to have been the first acceptance of the concept in English law, tailored to a special class of cases (Kinnear and Jones 1956:64), ${ }^{7}$ with the result of a conviction in England and Wales being that the range of sanctions available for manslaughter would apply. ${ }^{8}$ The infanticide provision required the courts to interpret the relationship between actus reus and a disease of the mind de novo (Walker 1968:131) where the M'Naghten rules would not be satisfied, but without this being adopted

7. Writing a dissent to the Report, Kinnear and Jones (1956) were calling for the adoption of a general diminished responsibility plea in Canadian (and English) law. The measure, found in Scottish law, was adopted in England and Wales in 1957, but has never been adopted in Canadian law, outside its limited incarnation with respect to infanticide. For a discussion of the historical development of partial defences in another former English colony, see Law Reform Commission, New South Wales 1993).

8. The fact that an infanticide finding could, in theory, have resulted in a life sentence, a prospect which seems to have prevented such findings in cases where the child died of neglect (see Davies 1968[1937-8]:317), may have been rendered less problematic for juries by the law being ostensibly based on a special kind of mental defect which would presumably have made such a sentence highly unlikely. In any event, the law was adopted and used, and the sentences were invariably lenient. 
as a general principle. Indeed, the principle was extremely narrow; the practice of "illegitimate mothers" killing newly born infants for socioeconomic reasons was reframed in legal discourse as rooted in mental derangement brought on by the effects of pregnancy and childbirth.

Medical experts were as likely as jurors to account for infanticide in socioeconomic terms although, as we have seen, they had a somewhat different population in mind from the "traditional" young, unwed defendants who were so hard to convict. The interpretation of responsibility underlying the English Infanticide Act 1922, an interpretation adopted in the Canadian legislation of 1948, was thus at variance with the categories of contemporary medical knowledge. "Lactational insanity" and "exhaustion psychosis," as understood by medical specialists, offered a challenge to fundamental legal doctrines in association with infanticide since the impetus to commit infanticide was explained mainly by socioeconomic factors external to the individual perpetrator-mother, extending responsibility to "society" and the experience of "workingclass motherhood." The Act's common-sense appeal to the biopsychological effects of childbirth and, after 1938, of lactation "itself," rather than the socioeconomic factors underpinning the medical diagnoses of exhaustion psychosis in lactating women, effectively met the criminal law's requirement that the individual, rather than society, be held accountable, even for an event widely thought of as only quasi-criminal (Ward 1999:174). ${ }^{9}$ The sentencing discretion available to English judges under the manslaughter scheme, and subsequently to Canadian judges faced with specific maximum sentences, allowed the women's social circumstances to be taken into account post conviction, but the primary question of guilt concerned the accused as formal legal, and possibly partly deranged, subject. ${ }^{10}$ It is regarding this individualism of infanticide law that the autopoiesis theory is most convincingly supported, and where Ward's identification of the biological theory of the 1922 Act as

9. Even after the amendments of 1938, the English infanticide law operationalized only medical-scientific knowledge of the mind in accordance with the legal convention that held the individual responsible for a crime.

10.Despite the discretion available to judges under this, and the subsequent, Canadian schemes, the offence of infanticide, partly through its individualization of mitigation, was rendered more serious than the offences previously exculpated by jurors, and sometimes judges, on socioeconomic grounds. This was, in one sense, the intent of the legislators; by offering juries a charge less serious than the murder charges jurors routinely rejected, the legislators hoped to secure convictions and sanctions appropriate to a homicide. Furthermore, sentencing decisions should reflect more than a precise level of culpability, including best strategies for individual rehabilitation and the need for general and specific deterrence. 
inimical to the thinking of contemporary psychiatry is most telling. The "psychiatric" mitigation embodied in the Act is, it turns out, not at all a reflection of any individualist and antisociological bias of biopsychiatry, but of a legal desideratum at odds with medical science. In adopting a very similar measure, this crucial aspect of infanticide law was simply absorbed into the Criminal Code of Canada without any pressure for the medicolegal issue to be debated.

Despite the attempt to mimic the English law, the enacted Canadian legislation differed from the English scheme in the manner of its application. This led to problems for the Canadian courts which required amendment. It is understandable that Canadian legislators missed these technicalities, but one wrinkle in the Canadian Parliament's attempt to rely on established English law is genuinely surprising; the Canadian Act of 1948 was based on the English Infanticide Act (1922), and not the amended version which had been operating in England for ten years.

\section{The Parliamentary Debate of 1948}

When the original omnibus bill containing the new infanticide statute was debated during its second reading in 1948, the Canadian legislators were reassured that they could adopt their own version of the English law with the confidence that it had been applied in England and Wales since 1922. According to Ilsley, the Canadian Minister of Justice:

Many years ago in England, the crime of infanticide was created by statute. It applies to cases where there is not the degree of mental derangement amounting to insanity.... We have taken the wording of the English statute. Those words are found in section 7, and there are English cases on this section. Therefore we are not without precedent to guide judges and juries in determining the circumstances in which a charge of infanticide is proper. (House of Commons Debates, 5, 14 June 1948:5185)

Legislators who contributed to the debate (all of whom were lawyers) were concerned with a range of issues in homicide law, of which infanticide was only one. ${ }^{11}$ For example, one member raised the issue of peace officers killing fleeing suspects and felt that such an instance should be dealt with as another separate kind of killing with reduced or no punishment. Another member raised the issue of the killing of chil-

11. Other issues raised in the debate were also mentioned in the press. For instance, Ilsley had redrafted a section of the Criminal Code dealing with "criminal sexual psychopaths" which would allow courts to issue indeterminate sentences following a conviction for a sex crime, to "remove sex offenders from circulation for an indefinite period and give them treatment which might lead to their release without menace to society" (Globe and Mail 1948:3). 
dren by motor cars, particularly by drunken drivers, and suggested that this kind of killing be dealt with more harshly to deter the large number of vehicular homicides of children. ${ }^{12}$ The discussion of the proposed infanticide amendment also covered wide ground, including, briefly, the potentially controversial broader legal implications of the introduction of what amounted to a defence of diminished responsibility to circumvent the death penalty. There was no debate about the scientific validity of the apparently medical concepts of mind incorporated into law, either in the House or in the newspaper reports that followed. The relevant headline in the Globe and Mail the following day did not even refer to infanticide, instead reading: "Death Penalty to Stay in Canadian Statutes, Ilsley Tells Commons" (Globe and Mail 1948:3). The headline reflected issues raised by John G. Diefenbaker (PC, Lake Centre) and Stanley H. Knowles (CCF, Winnipeg North Centre) concerning the possible abolition of the death penalty, including the law's deterrent value, the kinds of circumstances to which it would apply, and public opinion on the matter. In the shadow of these discussions, infanticide law became the vehicle for raising broader issues associated with the practice of capital punishment; the debate on the infanticide amendment provided legislators with the opportunity to raise questions about provocation, diminished responsibility, and punishment relating to a range of apparently more pressing social issues.

These kinds of quasi-social and legal questions were much more in the minds of legislators than the biological and apparently medical concepts upon which the statute relied. There seemed little or no question that pregnancy and childbirth produced, or could produce, a state of diminished capacity in women partially exculpating them for culpable homicide. The content of the debate illustrates that infanticide law arrived in Canada, not as new biomedical or psychiatric knowledge, but as a tried and tested mechanism for dealing with the legal problem of too few and inappropriate convictions. Both the death penalty and life imprisonment were popularly and judicially viewed in Canada, as in England and Wales, as inappropriate sanctions for many cases of infanticide, and had been so viewed for many decades (Kramar 2005:72-96). In this context, the passage of the infanticide statute, with its original maximum penalty of three years' imprisonment, provided the courts with the flex-

12.Widespread concern about the high numbers of children killed by the new motorcars in Canada and the United States had emerged prior to World War II, resulting in public health campaigns to teach children to play in the newly developed "playgrounds" rather than the streets and in the development of criminal justice measures aimed at deterring drivers from so-called reckless driving (see Zelizer 1985:32-50). 
ibility to issue fair punishment based on the circumstances of individual cases, and with culpable homicide, appropriate in light of the evidence, formally registered. Whilst the new statute had the potential to eventually medicalize the popular understanding of infanticide, at the point at which the law was passed, medical specialists in insanity had little, if anything, to do with altering the law.

According to news reports (Ottawa Evening Citizen 1948:8), the infanticide amendment was suggested by the Ontario provincial Attorney General, supported by Diefenbaker and easily passed in Parliament. ${ }^{13}$ The contemporary legal practice of charging women with "concealment of birth" was thought to discredit the application and practice of law (Globe and Mail 1948:3). As a substantive charge allowing for partial exculpation, infanticide law rationalized existing legal practices and addressed the punishment problem during a time in Canadian legal history when legislators were concerned with the potential negative effects of discretion by both juries and prosecutors. In the House of Commons, Mr. Ilsley, the Minister of Justice, described the situation as follows:

My information is that there are cases where the mother kills her newborn child, and that in the normal case of that kind it is useless to lay a charge of murder against the woman, because invariably juries will not bring in a verdict of guilty. They have sympathy with the mother because of the situation in which she has found herself. Therefore, crown prosecutors, and those who lay charges, if they are to obtain convictions lay charges of concealment of birth; or a charge that is equal to concealment of birth. Anyone who looks at the section will see that it is really not concealment of birth, but rather concealment of the body. However, this charge is known as concealment of birth. Sentences of a few months, or even shorter are imposed. To a minor extent that brings the law into disrepute, because the offence is murder; that is, unless the woman is insane (House of Commons Debates, 5, 14 June 1948:5185).

Ilsley justified the proposed tariff mostly by reference to existing practice:

We have placed the penalty at three years. It is purely a matter of judgement; the time may be too short, or it may be too long. I am told, however, that even in cases where manslaughter has been charged and convictions obtained - and I should think quite improperly, because I cannot think how a charge of that kind would have any of the elements of manslaughter

13.At the time, J.G. Diefenbaker (PC, Lake Centre) was the Conservative Party's justice critic. As a defence attorney, he privately opposed the death penalty. As justice critic, he was centrally involved in debates surrounding the abolition of the death penalty. 
- sentences have been rarely more than two years (House of Commons Debates, 5, 14 June 1948:5185).

Diefenbaker also made it clear that the infanticide provision was necessary to circumvent sympathetic jurors and gain convictions for a unique kind of homicide:

For in a great number of cases in which a woman finds herself in the position of having on her hands a newborn child, loses her power of control and the child dies in consequence of some act on her part, over and over again juries have refused to convict, regardless of the evidence. I presume that the reason for the amendment is to make it easier to get a conviction for the offence of homicide short of murder or manslaughter (House of Commons Debates, 5, 14 June 1948:5184).

This led to some discussion about the dangers of implementing new categories of culpable homicide to dodge the death penalty, rather than abolishing the death penalty altogether. ${ }^{14}$ Diefenbaker asked whether a complete revision might otherwise be more effective:

In view of the fact that something is being done to amend the criminal code by sections, I ask the minister if any consideration has been given to this matter [the death penalty]. I have the feeling that taking the code in this manner, and having a kind of selective amendment of it, may cause some difficulties in the future which I think are fairly obvious. But if the decision has been made to follow this course in order to meet certain ad hoc matters that have arisen in the last year, and if it is thought that this is the best way of doing so short of a complete revision, naturally I support it (House of Commons Debates, 5, 14 June 1948:5184).

The measure was, then, considered debatable because it represented a small but potentially significant shift in death penalty policy, not because there was something especially important about the incidence of infanticide, its perpetrators, or even its victims.

It is clear from the Hansard record that the Canadian infanticide law was a widely accepted solution to the twin legal problems of judicial and juror sympathy - leading to acquittals for murder and manslaughter and the alternative of laying concealment of birth charges - thought to be often too weak and always factually inappropriate. The infanticide amendment provided suitable middle ground. Indeed, since they had several years' English experience with an infanticide provision on which they could rely, the legislators seemed content to have been pre-

14. Moves to abolish the death penalty were well underway in England during this time. 
sented with a ready-made solution to a small but troublesome criminal justice problem, and unconcerned with the character and merits of the underlying "psychiatric" rationale of the measure they were adopting. The legislators were plainly oblivious to the significance of the changes enacted through the English Infanticide Act (1938), which did a little, at least, to bring the English law into line with the socioeconomic cast of contemporary psychiatric thinking regarding infanticide. Instead, the Canadian Parliament adopted a measure close to the superseded English Infanticide Act (1922), content that "its" application for over a quarter of a century ensured it was a sound legal measure.

\section{The Amendments of 1955}

The most obvious difference between the English Infanticide Act (1938) and the Canadian Infanticide Act (1948) was that, in adopting language modelled on that of the English Infanticide Act (1922) rather than the amended version of 1938, the Canadian legislation applied only to the "newly born." The 1922 Act did not contain the expanded age limit of 12 months defining "newly born" thus providing Canadian legislators with a legal definition of "infanticide" that much more closely reflected the circumstances of maternal neonaticide which had confounded the courts. Very shortly afterwards, in 1951, J. McRuer ruled in R. v. Marchello that, on grounds of common sense rather than any psychiatric theory, a child of four and a half months could not be considered "newly born" $(R . v$. Marchello, 1951, C.C.C. $137: 138-41) .{ }^{15}$ This interpretation was manifestly out of line with both psychiatric thinking and, probably more importantly, English practice and popular sympathies (Walker 1968:132), reflecting as it did the English jurisprudence relating to the 1922 Act, prior to its amendment in 1938 (Ward 1999:172). The issue was addressed by Parliament in the next consolidation of the Criminal Code in force in 1955. Following the 1938 English provision, "newly born" was defined as under the age of twelve months (Criminal Code, S.C. 1953-54, 2-3 Eliz. II, c. 51, s. 2[27]), and "the effects of lactation" added to the infanticide statute. With this revision, we observe the expansion of the formal psychiatric element to cover those cases of maternal neonaticide where the babies are more than a few hours or days old. This marked a shift towards a lay-psychiatric hybrid legal discourse in Canadian common law which began to include mitigation for the killings of older children by their mothers. These kinds of homicide were thus brought within the psychological framework of postpartum depression (and psychosis).

15. J. McRuer would subsequently chair a Royal Commission into the insanity defence; see McRuer Commission 1956. 
This expansion of the psychiatric element to cover cases where older children are killed by their mothers was eventually clawed back by those judges and jurors who did not want to allow mitigation when an unwed mother kills a newly born child in the context of postpartum depression. This development is ironic since the rejection of the infanticide defence may be largely a result of the concealment of the pregnancy indicating, for these jurors, intentionality on the part of the mother. For example, in a recent Canadian case, jurors in Wetaskiwin, Alberta convicted Katrina Effert of murder and sentenced her to life imprisonment for killing her newly born child. Neither the Crown, nor the jurors, were willing to extend the infanticide defence for the killing of a baby within hours of secret birth following a concealed pregnancy. Both forensic psychiatric experts who gave evidence for the Crown and the defence testified that Effert was suffering from a disturbed mind (Farrell 2006).

Despite the conscious effort to rely upon a tried and tested legal formula, the Canadian Parliament adopted a significantly different infanticide measure from the English law, which presented the courts with unanticipated problems. While it was possible under the English Infanticide Act (1922) to indict for infanticide (Davies 1968:335-6), the Canadian Act established the possibility of infanticide operating as a partial defence to a murder charge, putting the onus on the defence to present any available psychiatric evidence. When the Canadian scheme was set up in 1948, infanticide was constructed as a stand alone charge, and $\mathbf{J}$. McRuer ruled in Marchello that to prove guilt for infanticide, the Crown must establish the existence of a psychiatric disturbance. This provided sympathetic, indeed, even conscientious, juries with the opportunity to acquit for infanticide on the ground that the Crown had not met its burden where psychiatric evidence was impeached by the defence. A body of evidence suggesting wilful homicide in the absence of mental disturbance should lead to a complete acquittal for infanticide (Kinnear 1956:64), with double jeopardy preventing any possibility of retrial for the homicide! ${ }^{16} \mathrm{~J}$. McRuer considered the burden on the Crown he had been forced to outline too heavy, making it "almost impossible to convict an accused person on a charge of infanticide if laid as a single count in the indictment" (R.v. Marchello (1951) C.C.C. 137:158, n. 12). ${ }^{17}$

In the 1955 Criminal Code consolidation, the Canadian Parliament passed a measure which became s. 569 (Criminal Code, S.C. 1953-54,

16. This ruling was codified in what is now s. 610 (4) of the Criminal Code of Canada.

17. That this burden was thought by $\mathrm{J}$. McRuer to be overwhelming is evidence in itself that jurors were not relying upon the expert knowledge of biomedical psychiatry to guide their responses to infanticidal mothers. 
2-3 Eliz. II, c. 51, s. 569), dealing with convictions for "lesser included" offences. In cases where only murder has been charged but the case for murder has not been put, the section specifically allows the trier of fact to find for manslaughter or infanticide where the evidence warrants it. ${ }^{18}$ This placed the Canadian law on the same footing as the English (Kinnear 1956:64). The Canadian legislators went further, however, enacting in the subsequent section (s. 570) an extraordinary measure allowing the trier of fact to convict for infanticide where it is charged, the homicide is shown to be wilful, and the psychiatric evidence is absent or unproven (Criminal Code, S.C. 1953-54, 2-3 Eliz. II, c. 51, s. 570). The provision is now s. 663 of the Criminal Code of Canada:

No acquittal unless act or omission not wilful - Where a female person is charged with infanticide and the evidence establishes that she caused the death of her child but does not establish that, at the time of the act or omission by which she caused the death of the child,

(a) she was not fully recovered from the effects of giving birth to the child or from the effect of lactation consequent on the birth of the child, and

(b) that the balance of her mind was, at that time, disturbed by reason of the effect of giving birth to the child or of the effect of lactation consequent on the birth of the child

she may be convicted unless the evidence establishes that the act or omission was not wilful.

The Canadian 1955 amendments, taken together, can be said to have "embraced" the psychiatric understanding of postpartum mental illness underlying the English amendment of 1938 without the expert psychiatric evidentiary burden to confirm a diagnosis.

In the debate on the proposed s. 570, Stanley Knowles (CCF, Winnipeg), who had participated in the 1948 debate regarding the original Canadian infanticide statute, expressed concern about the removal of significant evidentiary burdens on the Crown, and the possibility that the double negative in the final clause could be read as placing the burden on the accused to prove her innocence through nonwilfulness. Another

18. This is now s. 662 (3) of the Criminal Code of Canada. The wording was interpreted in the British Columbia Provincial Court ruling in R. v. Lalli as making infanticide unavailable as a lesser included offence where manslaughter is charged; R. v. Lalli [1993] B.C.J. No. 2010 (P.C.B.C.) (QuickLaw). Adding to the complexity, "concealment of birth" was retained as a lesser included offence for murder and infanticide, reflecting the old jury practices that infanticide law was intended to negate; see current s. 662 (4) of the Criminal Code of Canada. 
member attempted to reassure the House that infanticide convictions were so difficult to obtain, that the new measure should not be cause for concern, and the measure was subsequently passed (Kramar, 2005:108).

Both statutes remain in force. ${ }^{19}$ The result of these amendments is that, where the Crown charges murder, the defence may well lead psychiatric evidence in partial defence, but the Crown can secure a conviction without it. ${ }^{20}$ Whatever the formal psychiatric underpinning of the infanticide law itself, and we have seen that establishing the nature of this is far from straightforward despite the apparent conceptual simplicity of the law, the new s. 570 reduced it to "mere words" of no necessary legal significance.

At the same time, the maximum penalty for infanticide was raised from three to five years, with little debate, as part of a standardization of the Criminal Code punishment framework (Criminal Code, S.C. 1953-54, 2-3 Eliz. II, c. 51, s. 208). Knowles was the only member of Parliament to question whether five years was not too harsh a penalty, asking if it

is not a rather severe sentence in view of the definition of infanticide that we have already been given.... As I understand the definition, there is imported into it exceptional or unusual circumstances. It seems to me that causing the death of a child, in the sense of it being outright murder, is covered in other sections. Causing the death of an unborn child is covered in clause 209. But I come back to the questions, namely, in view of the fact that infanticide is defined as something that happens under exceptional and understandable circumstances, is it not rather severe to increase the penalty from three to five years? (House of Commons Debates, 3,25 February 1954:2446)

In contemporaneously removing the requirement for the Crown to prove mental disturbance, the Canadian Parliament was, however, eliminating any necessary consideration of these "exceptional and understandable circumstances," beyond the circumstance that a mother had killed one of her children in the first year of its life.

\section{Conclusion}

The enactment and amendment of Canada's infanticide statute conforms to Ward's claim that infanticide law should not be read as an incursion

19.See Criminal Code of Canada, s. 662(3) and s. 633).

20.This allows the Crown to use the threat of a charge of murder to secure a guilty plea to manslaughter (see Kramar 2005:166-186), a possibility unlikely to have been in any legislator's mind in the 1950s. 
of professional biopsychiatric theory or expertise into law. Indeed, the argument is only stronger in Canada, where neither psychiatric theory nor psychiatrists seem to have had anything to do with the legislation. If Ward is correct in arguing that the embedding of a "biological theory" in the 1922 Act should not be taken as proof of the medical professional's colonization of law, being, surprisingly, the persistence of a lay theory in the face of contrary psychiatric thinking, then the Canadian development of 1948 was merely the pragmatic adoption of second-hand common sense.

Whilst psychiatric theory, although not any especially biopsychiatric theory, was reflected in the English legislation of 1938, the Canadian Parliament ignored this development in 1948, and adopted an equivalent of the measure the United Kingdom Parliament had amended on the mistaken ground that the English law had been in effect and solving the legal problems associated with infanticide for a quarter of a century. In an equally odd twist, they adopted the measure in a form which presented unique problems to the Canadian courts, with the Crown required to prove the mental disturbance to secure a conviction when juries were apparently more than willing to take the opportunity to reject any such evidence led by the Crown. Although the Canadian provision required psychiatric evidence only for its own strictly legal purpose of determining the level of responsibility for a culpable homicide, even without reflecting contemporary psychiatric thinking, this proved to be too much psychiatry for the law! The Canadian legislation was brought into greater harmony with the English Infanticide Act (1938) during the 1955 consolidation of the Criminal Code of Canada by including reference to the effects of lactation, extending the application of the statute to victims under the age of one year, and allowing infanticide to be a lesser included offence in an appropriate murder charge. However, the Canadian Parliament went much further, entirely eliminating the need for mental disturbance, or its causation by the reproductive process, to be proved for an infanticide conviction to be sustained, thereby potentially ripping the biopsychiatric heart out of infanticide law.

In many respects, then, Ward's critique of the medicalization interpretation of English Infanticide law is supported by the Canadian legislative history. His qualified invocation of the theory of law as an autopoietic system of communication is less helpful. Infanticide law is not an example of the subtle "enslavement" of psychiatric knowledge by the system of law working above the heads, or behind the backs, of legislators and jurists. While it may be conceded that the individualistic biologism of the 1922 template might be seen as subtly meeting a purely legal desideratum in a way that conforms to the autopoiesis theory, in 
most respects the English and Canadian Acts were the conscious work of legally focused legislators. In the Canadian case, at least, the legislation drew upon the legal expertise of Members of Parliament who were experienced lawyers. ${ }^{21}$ Ward's claims that the English Parliamentarians of 1922 imbued their Act with a lay biological theory, which had later to be corrected to conform to contemporary psychiatric theory, suggest purely factual limitations to an autopoietic theorization of the development of infanticide law. Given the available legal expertise, the most surprising aspects of the Canadian events are that the 1948 Act was out-ofdate at its adoption and poorly constructed in purely legal terms, while the "corrections" of 1955 remain legally problematic, leaving a statute with a stated basis in mental disturbance potentially devoid of its own rationale. "Law" has yet to tame the Canadian infanticide scheme into convincing legal coherence. Certainly, this process has left little defensible psychiatric knowledge regarding infanticide intact in the wording of the Canadian law but, whatever its merits regarding other legal issues, ${ }^{22}$ the theory of law as an autopoietic system of communication is simply too subtle, formal, antihumanistic, and sociologically deterministic to account for the developments; here, it would be a surgical saw used to crack a nut.

21.The adopted law's individualism diminished the possibility that legislators adding a new kind of mitigation to the homicide law of Canada would perceive a red flag, so that even the more subtle influences of "law" on the legislators can be cast in terms more humanistic than autopoiesis theory allows. However, this claim, containing as it does a counterfactual, can never be more than speculation.

22. One might more plausibly claim that the anonymous enslavement of psychiatric medical concepts occurred in the development and deployment of M'Naghten-based English and Canadian insanity law. The M'Naghten Rules, with their focus on delusions understood as wrong beliefs, clearly reflected contemporary psychiatric preoccupations, but transformed the psychiatric foci into distinctly legal constructs widely perceived by psychiatrists to be at odds with the fundamentals of psychiatric understanding (see Teubner, 1989:748-9; see also Forshaw and Rollin 1990:75-101). While the maintenance of legal principles of personal responsibility has clearly been a priority of jurists and legislators formulating insanity law, most have also been concerned to accommodate psychiatric knowledge. That this has proven difficult is feathers in the caps of autopoiesis theorists. Very little comparable medicolegal effort has been expended in the development of infanticide law. 


\section{REFERENCES}

Backhouse, C. 1984. Desperate women and compassionate courts: Infanticide in nineteenth century Canada. University of Toronto Law Journal 34:447-478.

1991. Petticoats and Prejudice: Women and the Law in Nineteenth-century Canada. Toronto: Women's Press for the Osgoode Society.

Brockington, I. 1996. Motherhood and Mental Health. Oxford: Oxford University Press.

Comack, E. 1987. Women defendants and the "Battered Wife Syndrome": A plea for the sociological imagination. Crown Counsel's Review 5(1):6-10.

Cruikshank, W.H. 1940. Psychoses associated with pregnancy and the puerperium. Canadian Medical Association Journal 43(6):571-6.

Davies, D.S. 1968. Child killing in English law. In L. Radzinowicz and J.W.C. Turner, eds., The Modern Approach to Criminal Law. Nendeln, Leichtenstein: Kraus Reprint. Davies' paper originally published 1937/8.

Edwards, S. 1984. Women on Trial. Manchester: Manchester University Press.

Ellis, H. 1901. The Criminal. Third Edition. London: Walter Scott.

Farrell, J. 2006. Verdict shocks experts. Edmonton Journal (28 September).

Forshaw, D. and H. Rollin. 1990. The history of forensic psychiatry in England. In R. Bluglass and P. Bowden, eds., Principles and Practice of Forensic Psychiatry. Edinburgh: Churchill Livingstone.

Foucault, M. 1978. About the concept of the "dangerous individual" in 19thcentury legal psychiatry. In D.N. Weisstub. ed., Law and Psychiatry: Proceedings of an International Symposium held at the Clarke Institute of Psychiatry, Toronto, Canada, February 1977. New York: Pergamon Press.

Globe and Mail, The. 1948. Death penalty to stay in Canadian statutes, Ilsley tells Commons. The Globe and Mail (15 June).

Harris, J.S. 1936. Mental disorder associated with child-bearing. British Medical Journal 3929 (25 April):835-7.

Heath, C. 1908. Some Notes on the Punishment of Death. London: Society for the Abolition of Capital Punishment.

Higginbotham, A.R. 1992. "Sin of Age": Infanticide and illegitimacy in Victorian London. In K.O. Garrigan, ed., Victorian Scandals. Athens, Ohio: Ohio University Press.

Hopwood, J.S. 1927. Child murder and insanity. The Journal of Mental Science 73(1):95-108.

House of Commons Debates 5. 1948. Official Report of Debates of House of Commons (Hansard). Fourth Session - Twentieth Parliament. 11-12 George VI. Volume V. Ottawa: Edmond Cloutier, Printer to the King's Most Excellent Majesty, Controller of Stationary. 
House of Commons Debates 3. 1954. House of Commons Debates: Official Report (Hansard). First Session - Twenty Second Parliament. 2-3 Elizabeth II. Volume III. Ottawa: Edmond Cloutier, Queen's Printer and Controller of Stationary.

James, E.W.B. 1935. Prognosis of puerperal insanity. The Lancet 228 (5835):1515-6.

Kilpatrick, E. and H.M. Tiebout. 1926. A study of psychoses occurring in relation to childbirth. American Journal of Psychiatry 6(1):145-59.

King, M. 1993. The "truth" about autopoiesis. Journal of Law and Society 20(2):218-236.

Kinnear, H.J. and R.O. Jones. 1956. Appendix A to memorandum of dissent: Reasons for dissent, Chapter IV - Diminished responsibility. In Report of the Royal Commission on the Law of Insanity as a Defence in Criminal Cases (McRuer Commission). Hull, Canada: Queen's Printer.

Kramar, K.J. 2005. Unwilling Mothers, Unwanted Babies: Infanticide in Canada. Vancouver: University of British Columbia Press.

Kramar, K.J. and W.D. Watson. 2006. The insanities of reproduction: Medicolegal knowledge and the development of infanticide law. Social and Legal Studies 15(2):237-255.

Laster, K. 1989. Infanticide: A litmus test for feminist theory. Australian and New Zealand Journal of Criminology 22(3):151-66.

Law Reform Commission, New South Wales. 1993. Provocation, Diminished Responsibility and Infanticide. Australia: Law Reform Commission Publication.

Luhmann, N. 1982. The Differentiation of Society. S. Holmes, and C. Larmore, trans. New York: Columbia University Press. 1985. A Sociological Theory of Law. Second edition. M. Albrow, ed, E. King and M. Albrow, trans. London: Routledge and Kegan Paul. 1988. Closure and openness: On reality in the world of law. In G. Teubner, ed., Autopoietic Law: A New Approach to Law and Society. Berlin: de Gruyter.

McRuer Commission. 1956. Report of the Royal Commission on the Law of Insanity as a Defence in Criminal Cases (McRuer Commission). Hull, Canada: Queen's Printer.

MacDonald, J. 1847. Puerperal insanity. American Journal of Insanity 4(2):113-63.

O'Donovan, K. 1984. The medicalisation of infanticide. The Criminal Law Review (May):259-64.

Osborne, J. 1987. The crime of infanticide: Throwing the baby out with the bathwater. Canadian Journal of Family Law 6(1):47-59.

Ottawa Evening Citizen, The. 1948. The Ottawa Evening Citizen (15 June). 
Scutt, J.A. 1981. Sexism in criminal law. In S.K. Mukherjee and J.A. Scutt, eds., Women and Crime. Sydney: George Allen \& Unwin and Australian Institute of Criminology.

Showalter, E. 1985. The Female Malady: Women, Madness, and English Culture, 1830-1980. New York: Penguin Books.

Skottowe, I. 1942. Mental disorders in pregnancy and the puerperium. The Practitioner 148(3):157-163.

Smalldon, J.L. 1940. A survey of mental illness associated with pregnancy and childbirth. American Journal of Psychiatry 97(1):80-101

Smart, C. 1989. Feminism and the Power of Law. London: Routledge. 1992. Disruptive bodies and unruly sex: The regulation of reproduction and sexuality in the nineteenth century. In C. Smart, ed., Regulating Womanhood: Historical Essays on Marriage, Motherhood and Sexuality. New York: Routledge.

Smith, C. 2004. Autopoietic law and the "epistemic trap": A case study of adoption and contact. Journal of Law and Society 31(3):318-344.

Strecker, E.A. and F.G. Ebaugh. 1926. Psychoses occurring during the puerperium. Archives of Neurology and Psychiatry 15(2):239-52.

Teubner, G. 1988. Evolution of autopoietic law. In G. Teubner, ed., Autopoietic Law: A New Approach to Law and Society. Berlin: de Gruyter. 1989. How the law thinks: Toward a contructivist epistemology of law. Law and Society Review 23(5):727-757.

1990. Social order from legislative noise? Autopoietic closure as a problem for legal regulation. In G. Teubner and A. Febbrajo, eds., State, Law, and Economy as Autopoietic Systems. Milano: Giuffrè. 1993. Law as an Autopoietic System. Oxford: Basil Blackwell.

Valverde, M. 2006. The sociology of law as a "means against struggle itself." Social and Legal Studies 15(4):591-597.

Walker, N. 1968. Crime and Insanity in England. Volume I: The Historical Perspective. Edinburgh: Edinburgh University Press.

Ward, T. 1998. Law's truth, lay truth and medical science: three case studies. In H. Helen Reece, ed., Law and Science: Current Legal Issues Volume 1. Oxford: Oxford University Press.

1999. The sad subject of infanticide: law, medicine and child murder, 1860-1938. Social and Legal Studies 8(2):163-80.

Wilczynksi, A. 1991. Images of women who kill their infants: The mad and the bad. Women and Criminal Justice 2(2):71-88.

1997. Mad or bad? Child killers, gender and the courts. British Journal of Criminology 37(3):419-36.

Winslow, L.F. 1912. Insanity of Passion and Crime. London: John Ousley

Zelizer, V.A. 1985. Pricing the Priceless Child: The Changing Social Value of Children. New York: Basic Books. 
Kirsten Kramar is the Vice-President of the Canadian Law \& Society Association and is affiliated with the University of Winnipeg. Current research interests include: infanticide law, coronial inquests and inquiries, and the relations among medico-legal, feminist, and victims' rights discourses. Recent publications include: Unwilling Mothers, Unwanted Babies: Infanticide in Canada. Vancouver: University of British Columbia Press, (2005); Coroners' interested advocacy: Understanding wrongful accusations and convictions, Canadian Journal of Criminology and Criminal Justice 48(5):811-830 (2006); with William D. Watson, Insanities of reproduction: Medico-legal knowledge and the development of infanticide law, Social and Legal Studies 15(2):237-255 (2006).

k.kramar@uwinnipeg.ca

William Watson, Assistant Professor, Woodsworth College, University of Toronto teaches in the University of Toronto's undergraduate Criminology program. His academic interests include the practice of forensic psychiatry, psychopathy, the provision of services to subpopulations of mentally disordered offenders who are identified, or self-identified, as having special needs, and the place of critical social science in public policymaking. Recent publications include: Review of Christine Stevenson: Medicine and Magnificence: British Hospital and Asylum Architecture, 1660-1815 (New Haven: Yale University Press, 2000) in The Journal of Forensic Psychiatry, 12(3):722-725 (2001); with Kirsten Kramar, Insanities of reproduction: Medico-legal knowledge and the development of infanticide law, Social and Legal Studies 15(2):237-55 (2006); Psychodynamics and neuroscience: J. Reid Meloy on psychopaths' defences, summarized in: William Watson, reporter, Conference report: 18th annual day in psychoanalysis, Toronto, 2007, Canadian Journal of Psychoanalysis, forthcoming.

williamwatson@sympatico.ca 
